УДК 347.965 .1

DOI https://doi.org/10.32849/2663-5313/2020.3.53

Олена Алексєєва,

канд. юрид. наук, адвокат,

дочент кафедри загальних дисииллін

Міжнародного університету фінансів

\title{
ПРЕДСТАВНИЦТВО ПРАВ ТА ІНТЕРЕСІВ ОРГАНІВ ДЕРЖАВНОЇ ВЛАДИ ТА ОРГАНІВ МІСЦЕВОГО САМОВРЯДУВАННЯ У СУДОВИХ ОРГАНАХ В УМОВАХ АДВОКАТСЬКОЇ МОНОПОЛІЇ
}

У статті досліджено законодавство, що регулює відносини представництва прав та інтересів органів державної влади та органів місиевого самоврядування у судових органах в умовах адвокатської монополії, встановлені проблемні аспекти такого представництва.

Відповідно до Закону України «Про судоустрій і статус суддів» кожна особа в нашій державі має право на професійну правничу допомогу. Крім того, особа вільна у виборі свого захисника.

31 січня 2020 року в Україні представництво у судах усіх інстанцій здійснюється виключно прокурорами або адвокатами всіх фізичних та юридичних осіб, у тому числі органів державної влади та органів місиевого самоврядування.

Разом із тим у ч. $1 \mathrm{~cm}$. 60 Цивільного прочесуального кодексу України від 18.03.2004 № 1618-IV, ч. 1 cm. 58 Господарського прочесуального кодексу України від 06.11.1991 № 1798-ХII, ч. ч. 1 cm. 57 Кодексу адміністративного судочинства України від 06.07.2005 № 2747-IV передбачено, що представником у суді може бути адвокат або законний представник.

Проте згідно із Законом України «Про адвокатуру та адвокатську діяльність» несумісною з діяльністю адвоката є робота на посадах державних службовців та на посадах органів місцевого самоврядування.

Зараз органи державної влади та органи місиевого самоврядування позбавлені права на своє представниитво у суді, оскільки не можуть укласти договори про надання правової допомоги з адвокатами чи адвокатським бюро/адвокатським об'єднанням через відсутність механізму фінансування органам державної влади та органам місиевого самоврядування видатків на адвокатські послуги з державного бюджету.

Отже, органи державної влади та органи місцевого самоврядування позбавлені права на здійснення правосуддя.

Акиентовано увагу на тому, що відсутність механізму врегулювання порушеного питання призводить до позбавлення права органів державної влади та органів місиевого самоврядування на здійснення правосуддя, що є недопустимим явищем у правовій державі, якою є Україна відповідно до ст. 1 Конституиї Украӥни.

Ключові слова: органи державної влади, органи місцевого самоврядування, судові органи, адвокат, представництво.

Постановка проблеми. Відповідно до Закону України «Про судоустрій і статус суддів» кожна особа у нашій державі має право на професійну правничу допомогу. Крім того, особа вільна у виборі свого захисника.

Проте у Конституції України передбачено, що 31 січня 2020 р. здійснюється представництво органів державної влади та органів місцевого самоврядування в судах виключно прокурорами або адвокатами.

Разом із тим згідно із Законом України «Про адвокатуру та адвокатську діяльність» несумісною з діяльністю адвоката є робота на посадах державних службовців та на посадах органів місцевого самоврядування.

Таким чином, на державній службі та в органах місцевого самоврядування не можуть працювати адвокати.

Зараз органи державної влади та органи місцевого самоврядування позбавлені права на своє представництво у суді, оскільки не можуть укласти договори про надання правової допомоги з адвокатами чи адвокатським бюро/адвокатським об'єднанням через 
відсутність механізму фінансування органам державної влади та органам місцевого самоврядування видатків на адвокатські послуги з державного бюджету.

Отже, органи державної влади та органи місцевого самоврядування позбавлені права на здійснення правосуддя, що $є$ недопустимим явищем у правовій державі, якою $€$ Україна відповідно до ст. 1 Конституції України.

Аналіз останніх досліджень та публікацій. Окремі питання адвокатської монополії вивчали юристи-практики та різні органи державної влади, у тому числі Конституційний Суд України. Разом з тим науковцями це питання не досить досліджене.

Метою цієї статті є аналіз норм чинного законодавства щодо можливого механізму реалізації права органів державної та влади та органів місцевого самоврядування на судовий захист.

Виклад основного матеріалу дослідження. В Україні організацію судової влади та здійснення правосуддя, що функціонує на засадах верховенства права відповідно до європейських стандартів і забезпечує право кожного на справедливий суд, визначає Закон України «Про судоустрій і статус суддів» від 02 червня 2016 р № 1402-VIII.

Відповідно до ч. 2 ст. 9 Закону суд створює такі умови, за яких кожному учаснику судового процесу гарантується рівність у реалізації наданих процесуальних прав та у виконанні процесуальних обов'язків, визначених процесуальним законом.

Згідно зі ст. 10 Закону кожен має право на професійну правничу допомогу. У випадках, визначених законом, держава забезпечує надання професійної правничої допомоги безоплатно.

Кожен є вільним у виборі захисника своїх прав та особи, яка надає правничу допомогу.

Для надання професійної правничої допомоги діє адвокатура. Забезпечення права на захист від кримінального обвинувачення та представництво в суді здійснюються адвокатом, за винятком випадків, установлених законом.

Разом із тим у ст. $131^{2}$ Конституції України від 28.06.1996 № 254к/96-ВР передбачено, що для надання професійної правничої допомоги в Україні діє адвокатура.

Незалежність адвокатури гарантується.

Засади організації і діяльності адвокатури та здійснення адвокатської діяльності в Україні визначаються законом.

Виключно адвокат здійснює представництво іншої особи в суді, а також захист від кримінального обвинувачення.
Законом можуть бути визначені винятки щодо представництва в суді у трудових спорах, спорах щодо захисту соціальних прав, щодо виборів та референдумів, у малозначних спорах, а також стосовно представництва малолітніх чи неповнолітніх осіб та осіб, які визнані судом недієздатними чи дієздатність яких обмежена.

Відповідно до пп. 11 п. $16^{1}$ Конституції України представництво відповідно до пункту 3 частини першої статті $131^{1}$ та статті $131^{2}$ цієї Конституції виключно прокурорами або адвокатами у Верховному Суді та судах касаційної інстанції здійснюється з 1 січня 2017 року; у судах апеляційної інстанції - 31 січня 2018 року; у судах першої інстанції - з 1 січня 2019 року.

Представництво органів державної влади та органів місцевого самоврядування в судах виключно прокурорами або адвокатами здійснюється з 1 січня 2020 року.

Таким чином, з 1 січня 2020 року представництво у судах усіх інстанцій здійснюється виключно прокурорами або адвокатами всіх фізичних та юридичних осіб, у тому числі органів державної влади та органів місцевого самоврядування.

У ст. 7 Закону України «Про адвокатуру та адвокатську діяльність» від 05 липня 2012 р. № 5076-VI передбачено, що несумісною з діяльністю адвоката є:

1. Робота на посадах осіб, зазначених у п. 1 ч. 1 ст. 4 Закону України «Про засади запобігання і протидії корупції», а саме:

1) особи, уповноважені на виконання функцій держави або місцевого самоврядування:

а) Президент України, Голова Верховної Ради України, його перший заступник та заступник, Прем'єр-міністр України, перший віце-прем'єр-міністр України, віцепрем'єр-міністри України, міністри, інші керівники центральних органів виконавчої влади, які не входять до складу Кабінету Міністрів України, та їх заступники, Голова Служби безпеки України, Генеральний прокурор України, Голова Національного банку України, Голова Рахункової палати, Уповноважений Верховної Ради України з прав людини, Голова Верховної Ради Автономної Республіки Крим, Голова Ради міністрів Автономної Республіки Крим;

б) народні депутати України, депутати Верховної Ради Автономної Республіки Крим, депутати місцевих рад;

в) державні службовці, посадові особи місцевого самоврядування;

г) військові посадові особи Збройних сил України та інших утворених відповідно до законів військових формувань, крім військовослужбовців строкової військової служби 
та військовослужбовців служби за призовом під час мобілізації, на особливий період стосовно їхньої підприємницької діяльності;

г) судді Конституційного Суду України, інші професійні судді, Голова, члени, дисциплінарні інспектори Вищої кваліфікаційної комісії суддів України, службові особи секретаріату цієї Комісії, Голова, заступник Голови, секретарі секцій Вищої ради юстиції, а також інші члени Вищої ради юстиції, народні засідателі і присяжні (під час виконання ними цих функцій);

д) особи рядового i начальницького складу органів внутрішніх справ, державної кримінально-виконавчої служби, Державної служби спеціального зв'язку та захисту інформації України, податкової міліції, особи начальницького складу органів та підрозділів цивільного захисту;

е) посадові та службові особи органів прокуратури, Служби безпеки України, дипломатичної служби, доходів і зборів;

є) члени Центральної виборчої комісії;

ж) посадові та службові особи інших державних органів, органів влади Автономної Республіки Крим;

2) особи, які прирівнюються до осіб, уповноважених на виконання функцій держави або місцевого самоврядування:

а) посадові особи юридичних осіб публічного права, які не зазначені в пункті 1;

б) особи, які не є державними службовцями, посадовими особами місцевого самоврядування, але надають публічні послуги (аудитори, нотаріуси, оцінювачі, а також експерти, арбітражні керуючі, незалежні посередники, члени трудового арбітражу, третейські судді під час виконання ними цих функцій, інші особи в установлених законом випадках);

в) посадові особи іноземних держав (особи, які обіймають посади в законодавчому, виконавчому або судовому органі іноземної держави, в тому числі присяжні засідателі, інші особи, які здійснюють функції держави для іноземної держави, зокрема для державного органу або державного підприємства), а також іноземні третейські судді, особи, які уповноважені вирішувати цивільні, комерційні або трудові спори в іноземних державах у порядку, альтернативному до судового;

г) посадові особи міжнародних організацій (працівники міжнародної організації чи будь-які інші особи, уповноважені такою організацією діяти від її імені), а також члени міжнародних парламентських асамблей, учасником яких є Україна, та судді і посадові особи міжнародних судів;

3) особи, які постійно або тимчасово обіймають посади, пов'язані $з$ виконанням організаційно-розпорядчих чи адміністративно-господарських обов'язків, або спеціально уповноважені на виконання таких обов'язків у юридичних особах приватного права незалежно від організаційно-правової форми, відповідно до закону;

4) посадові особи та працівники юридичних осіб - у разі одержання ними неправомірної вигоди, або одержання від них особами, зазначеними у пунктах 1 і 2 частини першої цієї статті, або за участю цих осіб іншими особами неправомірної вигоди;

5) фізичні особи - у разі одержання від них особами, зазначеними у пунктах 1-4 частини першої цієї статті, або за участю цих осіб іншими особами неправомірної вигоди.

2. Військова або альтернативна (невійськова) служба;

3. Нотаріальна діяльність;

4. Судово-експертна діяльність.

У разі виникнення обставин несумісності, встановлених частиною першою цієі статті, адвокат у триденний строк 3 дня виникнення таких обставин подає до ради адвокатів регіону за адресою свого робочого місця заяву про зупинення адвокатської діяльності.

Враховуючи викладене, несумісною 3 діяльністю адвоката $є$ робота на посадах державних службовців, на посадах органів місцевого самоврядування.

Разом із тим у ч. 1 ст. 60 Цивільного процесуального кодексу України від 18.03.2004 № 1618-IV, ч. 1 ст. 58 Господарського процесуального кодексу України від 06.11.1991 № 1798-XII, ч. ч. 1 ст. 57 Кодексу адміністративного судочинства України від 06.07.2005 № 2747-IV передбачено, що представником у суді може бути адвокат або законний представник.

Законом України «Про внесення змін до деяких законодавчих актів України щодо розширення можливостей самопредставництва в суді органів державної влади, органів влади Автономної Республіки Крим, органів місцевого самоврядування, інших юридичних осіб незалежно від порядку їх створення» від 18.12.2019 № 390-IX внесено зміни до Цивільного процесуального кодексу України, Господарського процесуального кодексу України, Кодексу адміністративного судочинства України та передбачено, що юридична особа незалежно від порядку іiі створення бере участь у справі через свого керівника, члена виконавчого органу, іншу особу, уповноважену діяти від іiї імені відповідно до закону, статуту, положення, трудового договору (контракту) (самопредставництво юридичної особи), або через представника. 
Держава, Автономна Республіка Крим, територіальна громада беруть участь у справі через відповідний орган державної влади, орган влади Автономної Республіки Крим, орган місцевого самоврядування відповідно до його компетенції, від імені якого діє його керівник, інша уповноважена особа відповідно до закону, статуту, положення, трудового договору (контракту) (самопредставництво органу державної влади, органу влади Автономної Республіки Крим, органу місцевого самоврядування) або через представника.

Проте зазначений Закон не вирішив питання щодо механізмів та способів представництва адвокатами органів державної влади та органів місцевого самоврядування у судових органах.

\section{Висновки}

31 січня 2020 року в Україні представництво у судах усіх інстанцій здійснюється виключно прокурорами або адвокатами всіх фізичних та юридичних осіб, у тому числі органів державної влади та органів місцевого самоврядування.

Проте несумісною з діяльністю адвоката $є$ робота на посадах державних службовців, на посадах органів місцевого самоврядування.

Проте на цей час не врегульовано питання умов представництва адвокатами органів державної влади та органів місцевого самоврядування. Особливої уваги заслуговує питання щодо оплати гонорарів адвокатів такими органами, оскільки вони фінансується із бюджету, в якому не передбачено коштів на такі витрати.

Таким чином, 31 січня 2020 року і по цей час органи державної влади та органи місцевого самоврядування позбавлені можливості свого представництва у судових органах адвокатами через відсутність механізму реалізації такого права. На законодавчому рівні відсутні чіткі умови роботи адвокатів з органами державної влади та місцевого самоврядування.

Проте навіть у разі законодавчого врегулювання питання щодо механізму представництва адвокатами органів державної влади та органів місцевого самоврядування залишиться досить велика кількість невирішених питань.
Так, юристи, які працюють в органах державної влади та органах місцевого самоврядування, більше орієнтуються в справах відповідної установи, ніж найнятий для представництва у суді адвокат. Адвокат не буде брати участі у підготовці рішень відповідного державного органу влади чи органу місцевого самоврядування чи в укладенні, внесенні змін або розірванні договорів. Ці питання будуть вирішувати штатні юристи. Тобто штатні юристи будуть готувати відповідні документи, а адвокати будуть лише представляти інтереси органів державної влади та органів місцевого самоврядування у судах. У чому сенс такої монополії?

На цей час це питання залишається відкритим i, сподіваюсь, що буде вирішене на законодавчому рівні найближчим часом.

\section{Список використаних джерел:}

1. Закон України «Про судоустрій і статус суддів» від 02 червня 2016 р. № 1402-VIII (станом на 16 жовтня 2019 р.) / Верховна Рада України. Офіиійний вісник Украйни. 2019. № 95 (10.12.2019). Ст. 3140.

2. Конституція України : Закон України від 28 червня 1996 р. № 254к/96-ВР (станом на 03 вересня 2019 р.) / Верховна Рада Украйни. Голос України. 2019, 12.09.2019, № 173.

3. Закон України «Про адвокатуру та адвокатську діяльність» від 05 липня 2012 р. № 5076-VI (станом на 17 жовтня 2019 р.) / Верховна Рада України. Урядовий кур'єр. 2019, 11, 16.11.2019, № 220.

4. Цивільний процесуальний кодекс України від 18.03.2004 № 1618-IV (станом на 15 січня 2020 р.) / Верховна Рада України. Офіційний вісник України, 2020, № 14 (21.02.2020). Ст. 543.

5. Господарський процесуальний кодекс України від 06.11.1991 № 1798-XII (станом на 15 січня 2020 р.) / Верховна Рада Украйни. Офіиійний вісник України, 2020, № 14 (21.02.2020). Ст. 543.

6. Кодекс адміністративного судочинства України від 06.07.2005 № 2747-IV (станом на 15 січня 2020 р.) / Верховна Рада Украйни. Офіиійний вісник України, 2020, № 14 (21.02.2020). Ст. 543.

7. Закон України «Про внесення змін до деяких законодавчих актів України щодо розширення можливостей самопредставництва в суді органів державної влади, органів влади Автономної Республіки Крим, органів місцевого самоврядування, інших юридичних осіб незалежно від порядку їх створення» від 18.12.2019 № 390-IX.

The article examines the legislation governing the relations between the representation of the rights and interests of public authorities and local self-government bodies in judicial bodies under the conditions of a lawyer's monopoly, identifies the problematic aspects of such representation.

In Ukraine, according to the Law of Ukraine "On Judiciary and Status of Judges", every person has the right to professional legal assistance. In addition, a person is free to choose their defender.

From January 1, 2020 in Ukraine, representation in courts of all instances is carried out exclusively by prosecutors or lawyers of all individuals and legal entities, including state authorities and local selfgovernment bodies. 
Meanwhile, in Part 1 of Art. 60 of the Civil Procedure Code of Ukraine of 18.03.2004 No. 1618-IV, part 1 of Art. 58 of the Commercial Procedure Code of Ukraine of 06.11.1991 No.1798-XII, Part 1 of Art. 57 of the Code of Administrative Judiciary of Ukraine of 06.07.2005 No. 2747-IV provides that a laweyer or legal representative may be represented in court.

At the same time, according to the Law of Ukraine "On Advocacy and Advocacy" incompatible with the activity of a lawyer is work in the positions of civil servants and in the positions of local self-government bodies.

At present, state and local governments are deprived of their right to represent themselves in court because they cannot conclude legal assistance agreements with lawyers or law firms/law firms due to the lack of funding mechanisms for government and local government fees for attorneys' fees from the state budget.

Thus, public authorities and local self-government bodies are deprived of the right to exercise justice.

Attention is drawn to the fact that the lack of a mechanism for regulating the raised issue leads to the deprivation of the right of state and local self-government bodies to exercisejustice, which is an inadmissible phenomenon in the rule of law, which is Ukraine according to Art. 1 of the Constitution of Ukraine.

Key words: public authorities, local governments, judicial authorities, lawyer, representation. 